DOI: $10.21448 / \mathrm{ijsm} .407285$

\title{
Features of the Proline Synthesis of Pea Seedlings in Depend of Salt and Hyperthermia Treatment Coupled with Ionizing Radiation
}

\author{
Olena Nesterenko (iD*1, Namik Rashydov (iD) 1
}

${ }^{1}$ Institute Cell Biology and Genetic Engineering of National Academy of Sciences of Ukraine, Kyiv, Ukraine.

\begin{abstract}
The proline is an important amino acid that takes part on live cell protection as well as adaptation processes to adverse environment stress factors. The effects of ionizing radiation coupled with salinity or hyperthermia stress factors on pea seedlings were investigated. Different growth reactions and free proline content in root of the Pisum sativum L. seedlings for all treatments were evaluated. The received results of growth parameters show that some doses of ionizing radiation assists to plants in resistance to salt and temperature stressors, however this resistance is short-term. Deviation of plants reactions from additive effect to synergism or antagonism that can represent crosstalk of signal system was observed. This work proves that concentration of proline depends of stressors kind, their combinations and doses. The free proline level is a result of opposite processes of its synthesis and destruction, release and binding. The quantification of this amino acid is useful to assess the physiological status of signal systems crosstalk and more generally to understand stress tolerance of plants.
\end{abstract}

ARTICLE HISTORY

Received: 06 January 2018

Revised: 23 February 2018

Accepted: 16 March 2018

\section{KEYWORDS}

Proline,

Salt stress,

Heat stress,

Ionizing radiation,

Signal systems crosstalk,

Pea,

Pisum sativum L.

\section{INTRODUCTION}

Investigation of plants response to different stress factors and their combination are going relevant in conditions of contrast changes of climatic situation and currently unstable ambient [1-2]. Special attention is paid to understanding the pathways and interconnections of signal systems and search for specific and nonspecific aspects of plant response during adaptation process. An abiotic stress is considered to be one of the main reasons for the loss of more than $50 \%$ harvest of different crops worldwide. For example, drought and salinity decrease crops yield by $20-40 \%$ and temperature increase above optimum as well as by $15 \%$ [3]. It is known that a pea is one of the most significant agricultural legumes. This dicotyledonous plant is nutritious and rich in protein, and is one of the very first an agricultural crop that was domesticated worldwide. Every year more than 7 millions hectares are planted with this crop, and up to 11 (dry) or 18 (green) millions tons of pea are produced [4]. It could be noted that influence of each stress factors on agrarian plants crop-producing is well studied separately. Nevertheless, in natural environment all living organisms are influenced by a combination of

CONTACT: Olena Nesterenko $\bowtie$ lena6q@ukr.net National Academy of Sciences of Ukraine, Kyiv, Ukraine 
different stress factors that affect plant's general condition and can lead to decrease in yields and speed up degradation and/or aging ones [5-6].

The proline (pyrrolidine- $\alpha$-carbon acid, $\mathrm{C}_{5} \mathrm{H}_{9} \mathrm{NO}_{2}$ ) is heterocyclic amino acid where Nitrogen atom is included in secondary but not primary amine and it is one of the most universal and multifunctional secondary metabolite in plants. The proline effect of a plant is most pronouncedly manifested in response to the influence of abiotic stress factors. Increase in proline level is widespread response to different stresses, particularly osmotic stress. Therefore, quantities analysis of this amino acid is a very useful tool for evaluation of plant's physiological condition and in for understanding plant's tolerance to stress influence. Currently it is considered that in addition to well-established osmoprotective function, proline may have chaperone, antioxidant signal regulating and other functions [12-13].

Signal systems crosstalk. Particularly important is research of changes of plant's response to one stress factor under influence of another that is search of interaction points - crosstalk. Combination of the response strategies of the living organisms to different factors may lead to crosstalk of signal systems [7]. It provides the optimal and adequate response and form biochemical pathways of plant's active reaction [8-9]. For example, both heat shock and salinity stress lead to changes in SOD (superoxide dismutase) and catalysis activity [10-11]. It serves a number of functions such as signaling for transitioning to flowering/bloom [14] or supporting normal development of the pollen and seed [15]. Proline content have a direct relation to antioxidant, osmo- and membrano-protective influence, takes part in regulation of antioxidant enzymes genes expression and in binding of metals with variable valence as well as influences NAD(P)H/NAD(P) balance. To detect the signal systems crosstalk we suggest set of experiments that based on morphometrical [16] and proline level measurements of plants. It was intended to identify respective stressors combinations in time to determine the role of each signal system on an example of stress proteins' spectrum and their concentration [17]. The known specificity and non-specificity of plant's response to different stress factors indicates the certain level of correlation between parts of different metabolic subprograms and reduce or eliminate the damaging influence of the stressor to the plant organism.

The aim of our research is to study the influence of ionizing radiation in combination with other abiotic stress factors such as salinity and temperature on plant's response. These data could integrally characterize molecular, genetic, structural and metabolic changes in pea seedlings on their initial growth phase.

\section{MATERIAL AND METHODS}

\subsection{Plant Material}

The pea seeds (Pisum sativum L.) of the variety "Aronis" grew up in a thermostat in roll culture. The parameters of the pea seedlings growth after influence of stress factors were evaluated. The seedlings were grown in hydroculture at a temperature of $23 \pm 2^{\circ} \mathrm{C}$ and illumination of $2286 \pm 224 \mathrm{Lx}$ on mode a dark-light cycle of 16 hours of light and 8 hours of darkness.

\subsection{Scheme of Experiment}

Pea seedlings at the stage of 3 days-old seedlings were exposed to stress factors. Acute X-ray irradiation was used as a stressor. The plants were irradiated by X-ray in apparatus RUM17 (National Institute of Problem Oncology and Radiobiology of NASU, Kiev, Ukraine) in dose rate of $89 \mathrm{cGy} / \mathrm{min}$ (photon energy $180 \mathrm{keV}$ ), and the total doses were varied within 0 - $25 \mathrm{~Gy}$ (previous experiments show that irradiation in dose $25 \mathrm{~Gy}$ is critical for pea seedlings and can cause visible long-term defects). Additionally, some seedlings after irradiation were exposed for one hour to hyper thermal stress (at the temperature $44^{\circ} \mathrm{C}$ for $4-8$ minutes in hydroculture) 
or to osmotic stress $(\mathrm{NaCl}$ solution at a concentration of $0.22 \mathrm{Mol})$. After that all seedlings were returned to hydroculture and continued growth in standard environment. Each experimental group contained 25-35 seedlings. Experiments had been repeated for three times.

In the course of two weeks after stressors exposure, parameters of seedlings growth were determined. The relative growth rate (RGR) was calculated as the ratio of growth of the main root in the experimental treatment in compare with control variant. The magnitude and sign of the modifying effect antagonism, additive or synergism of the preliminary irradiated plants were evaluated by comparing the current value of the RGR. The resulting RGR ratio was expressed as a percentage. The levels of proline content in the roots of plants were measured during the month. Mode of treatments of experimental groups is shown in Table 1.

Table 1. Stress factors and the scheme of experiment

\begin{tabular}{cccc}
\hline $\begin{array}{c}\text { Experimental } \\
\text { Group }\end{array}$ & Radiation (Gy) & $\begin{array}{c}\text { Stress Factors } \\
\text { Salinity } \\
(\mathrm{NaCl}, \mathrm{Mol})\end{array}$ & $\begin{array}{c}\text { Heat stress } \\
\left({ }^{\circ} \mathrm{C}\right)\end{array}$ \\
\hline 1 & 0 & 0 & $\mathrm{RT}$ \\
2 & 0 & 0.22 & $\mathrm{RT}$ \\
3 & 0 & 0 & 44 \\
4 & 5 & 0 & $\mathrm{RT}$ \\
5 & 5 & 0.22 & $\mathrm{RT}$ \\
6 & 5 & 0 & 44 \\
7 & 10 & 0 & $\mathrm{RT}$ \\
8 & 10 & 0.22 & $\mathrm{RT}$ \\
9 & 10 & 0 & 44 \\
10 & 15 & 0 & $\mathrm{RT}$ \\
11 & 15 & 0.22 & $\mathrm{RT}$ \\
12 & 15 & 0 & 44 \\
13 & 20 & 0 & $\mathrm{RT}$ \\
14 & 20 & 0.22 & $\mathrm{RT}$ \\
15 & 20 & 0 & 44 \\
16 & 25 & 0 & $\mathrm{RT}$ \\
17 & 25 & 0.22 & $\mathrm{RT}$ \\
18 & 25 & 0 & 44 \\
\hline
\end{tabular}

RT - room temperature.

\subsection{Measurement of Free Proline}

Ninhydrin reacts with all amino acids having an $\alpha$-amino group, giving a violet staining, with the exception of proline or hydroxyproline, in the reaction with which ninhydrin gives a yellow (orange) color. This colorimetric analysis is quantitative and provides reliable data on proline content, its sensitivity is about $1 \mathrm{nMol}$.

Proline is very soluble and can be easily extracted by heating the plant explants for 30 minutes in pure ethanol or in water. For measurement content of free proline the ninhydrin method was used [18]. Plant roots were chose to eliminate the influence of additional dyeing factors from vegetative materials on the color of the reaction. The plant material was frozen at $-40^{\circ} \mathrm{C}$ or dried at room temperature. Proline was extracted from dry samples. Mixture an ethanol and water at a ratio of 70:30 was used for extraction of proline. The roots of the seedlings were homogenized and centrifuged. The supernatant was collected in a clean tube. A mixture of $1 \%$ ninhydrin in acetic acid and ethanol was added to the reaction mixture and incubated at $95^{\circ} \mathrm{C}$ 
for 30 minutes. The tubes were cooled sharply on ice to stop the reaction. Mixture was centrifuged for 1 minute at $10000 \mathrm{rpm}$. The supernatant was taken out and transferred to the cuvettes. The optical density of the solution of ninhydrin-proline was determined at a wavelength of $520 \mathrm{~nm}$ on a spectrophotometer SF-26. The content of proline was determined from a calibration curve (Figure 1) constructed using standard solutions of L-proline at concentrations ranging from 0.04 to $1 \mathrm{mM}$. The level of free proline in control was taken at $100 \%$. Statistical processing of data on plant growth parameters and proline content was carried out at a $\mathrm{p}<5 \%$ confidence level using the standard methods of the Microsoft Excel 2007 package.

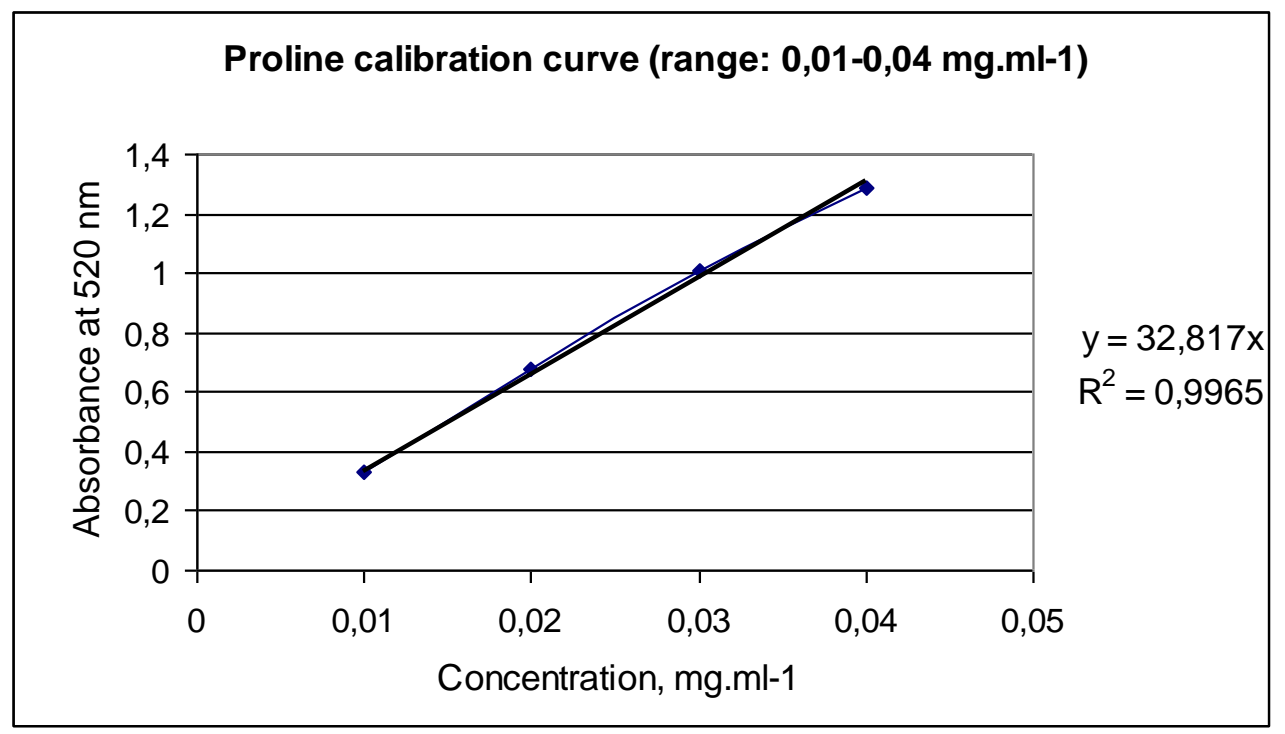

Figure 1. Calibration curve for evaluation of the free proline concentration

\section{RESULTS AND DISCUSSION}

\subsection{The Relative Growth Rate (RGR) Analysis of Seedlings after Stress Factors Impact}

According to measurements RGR of pea seedlings that were carried out 2 days after the influence of stress factors was built a chart. When the seeds are pre-irradiated at dose of $5 \mathrm{~Gy}$ and treated by heat shock the suffered effect significantly exceeded than was expected theoretically. It may indicate synergism between factors at appropriate doses (Figure 2, "5 Gy $+t^{\prime \prime}$ group). In this case the experimental group which was under the affect of salt stress after irradiation at the same 5 Gy showed absolutely opposite result. It may indicate the role of ionizing radiation as a "mitigating" salinity stress factor in this particular case.

The similar behavior of pea seedlings RGR was observed with groups that undergo preliminary radiation with 10 Gy coupled with hyperthermia or salinity stress (Figure 2). At irradiation 15 Gy we could clearly observe growth suppression of the stem and root but with relatively high survivability of plants. On the fourth day after $10 \mathrm{~Gy}$ irradiated and heat shock influenced, the seedlings had high RGR, in comparison with the group that only was irradiated. This may indicate that the radiation modifies responses to hyperthermia and switches on some mechanisms of protection in plants.

It was found that plant growth reactions and adaptations to stressors can be influenced by content of polyamines. Obviously, increase of their concentration may have adaptive role only while they don't exceed the physiologically optimal limits. For example, for plants with protein type metabolism (e.g. pea, bean etc.) acute salinity can cause severe protein metabolism disorder and eventually accumulation of polyamides to the toxic levels that later lead to necrosis 
[19]. While measuring growth reaction on term of RGR similar behavior of the relationship was observed especially when combining salinity influence with preliminary irradiation doses within 10-15 Gy.
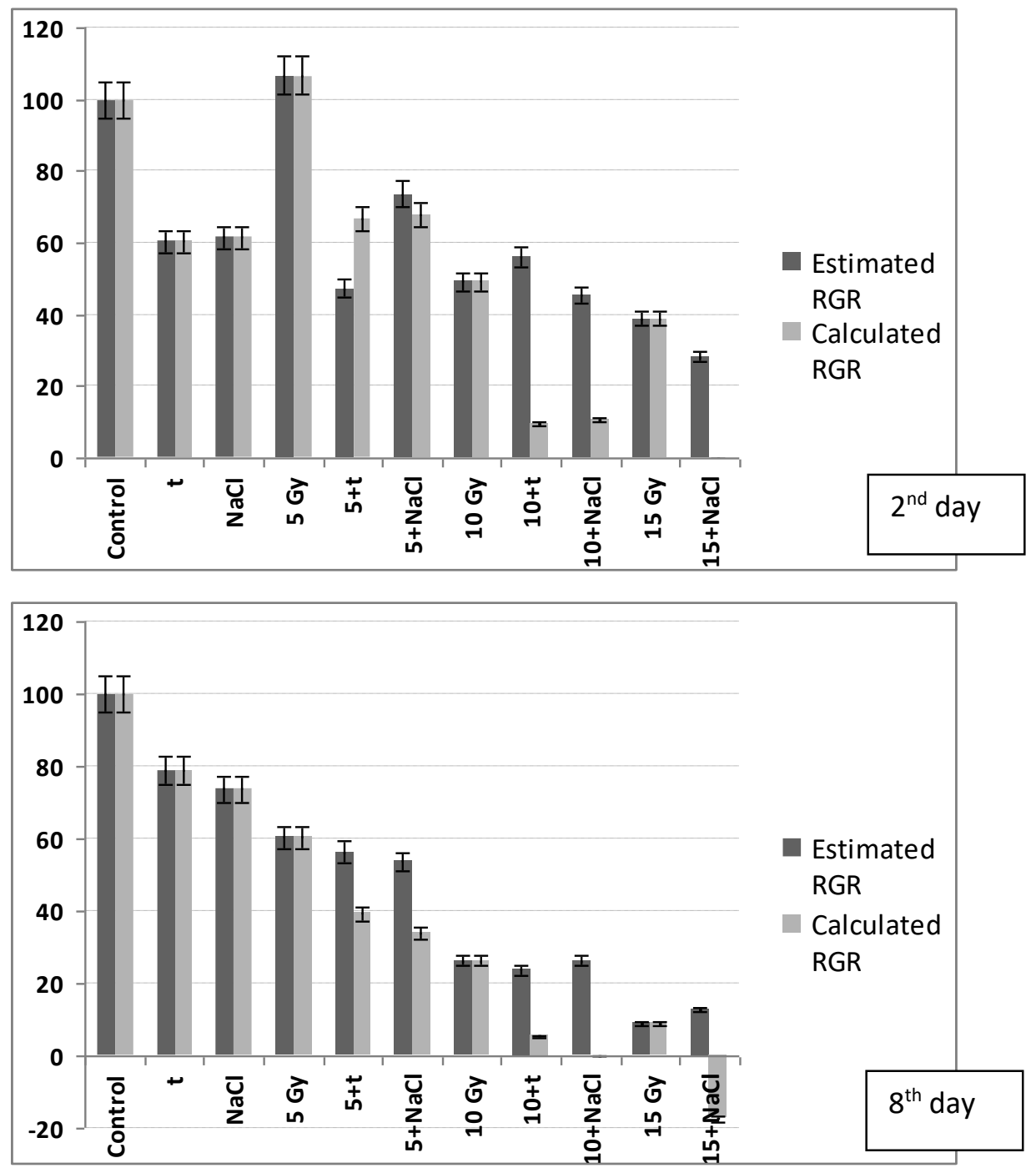

Figure 2. The impact of different doses of radiation coupled with hyperthermia or salinity stresses on the RGR of pea seedlings roots formation. $2^{\text {nd }}$ and $8^{\text {th }}$ days post-radiation term. (On Y axis - RGR, $\%$. On $\mathrm{X}$ axis - type of impact).

Plants condition begins gradually recover in time after stress affect. The influence of different doses of acute radiation and other stress factors are presented on Figure 2. The data between $2^{\text {nd }}$ and $8^{\text {th }}$ day show similar response to stresses. At the same time, we could clearly observe antagonistic effects of stress factors of different origin (either salinity stress or hyperthermia after irradiation of $10 \mathrm{~Gy}$ and $15 \mathrm{~Gy}$ ). It was found that plant's growth parameters exceed expectation.

On the $13^{\text {th }}$ day of the experiment the length of the main root did not exceed theoretical expectations in any experimental groups. However, peripheral roots demonstrated compensatory growth after full or partial suppression of the main root's function. Similar to the stem growth it is difficult to identify a clear pattern of peripheral roots formation in response to the impact of different stress factors. Stimulation of peripheral roots growth was observed at the 5 Gy dose. But irradiation of $10 \mathrm{~Gy}$ and $15 \mathrm{~Gy}$ suppressed peripheral roots appearing. On the $13^{\text {th }}$ day of pea seedlings development there was no clear relation between the stem growth 
and stressor dose but there was a positive correlation between stem and main root length during the experiment $\left(\mathrm{R}^{2}=0.89\right)$. At the same time the root development was suppressed more, than that stem of seedlings.

\subsection{Proline Content Measurement}

\subsubsection{Salt Stress in Combination with Preliminary Heat Shock}

In experiment carried out on wheat seedlings exposed to salinity with hyperthermia stresses was shown [19] that the ratio of amino acids (as well as proline) in roots has a positive correlation with stems. The roots of pea seedlings were used for the proline content measuring in our studies. We suppose that results obtained on roots can be projected on the whole plant.

The content of proline was measured in roots of pea seedlings in one week after stress impact. The amino acid level was significantly higher after heating with or without salinity stress (Figure 3). It can be suggested that high temperature has a stronger or more prolonged effect on pea seedlings than salinity stress only.

Short-term heating in combination with following salinity affect decrease level of proline content in the plant's roots more drastically than chloride salinity stress only. However, proline concentration in pea roots reached to its maximum after longer period of heating. It was significantly higher in compare to control group or any groups of treated plants (salinization with/without hyperthermia). In this case heat impact has modifying influence on proline accumulation process. Previously it was reported [19] that the inhibition of the corn seedlings growth by salinization may be increased by following hyperthermia. However, short-term heating of plants up to $40^{\circ} \mathrm{C}$ can significantly decrease the content of the proline level.

In two days after the simultaneous impact of hyperthermia and salinization on wheat seedlings the highest lever of proline accumulation was observed. Concentration of amino acid in experimental plants was 4-5 times higher in compare to control group [19]. It can be noted that heating seedlings up to $44^{\circ} \mathrm{C}$ for 4 and 8 minutes provokes acute increase of proline content up to about $40 \%$ above control level. This amino acid concentration significantly varies in groups of plants after heating and following salinization. In case of 4 minutes hyperthermia proline level decreased almost twofold in compare to salinization-only group; in case of 8 minutes - increased by quarter.

As it is known increase of proline level after either ionizing radiation or osmotic shock can be explained by its origin. Proline is a product of the cell membrane proline-containing proteins disintegration. It is fixed fact that the proline rich proteins (PRPs) are involved in the formation of cell wall [20-21].

In our experiment the plants after salinization and relatively long term heating for 8 minutes can have following disintegration of all proteins that leads to plant growth suppression and significant increase of proline content in roots. It is known that impact of any stress factors is accompanied by producing of reactive forms of oxygen (ROS) superoxide anion, hydroxylate anion, hydrogen peroxide etc. They can participate in nuclear acids or proteins damage and cause peroxidation of lipids in the live cell membrane [22].

Previously it was shown that preheating of pea seedlings to $35^{\circ} \mathrm{C}$ neutralized the decrease of proteins and DNA after salinization [19]. We can observe the same behavior in our experiments in groups of plants after combination of salinity and 4 minutes hyperthermia stresses. The following explanation of the different proline accumulation in different groups should not be excluded. The ability of spermine and proline to be long-distance transported through xylem and phloem from organs that undergo heat shock to other parts of plants is well known. Considering the transit nature of proline accumulation under the hyperthermia impact, we can assume that it participate in a stress signal transduction systems [23-24]. 


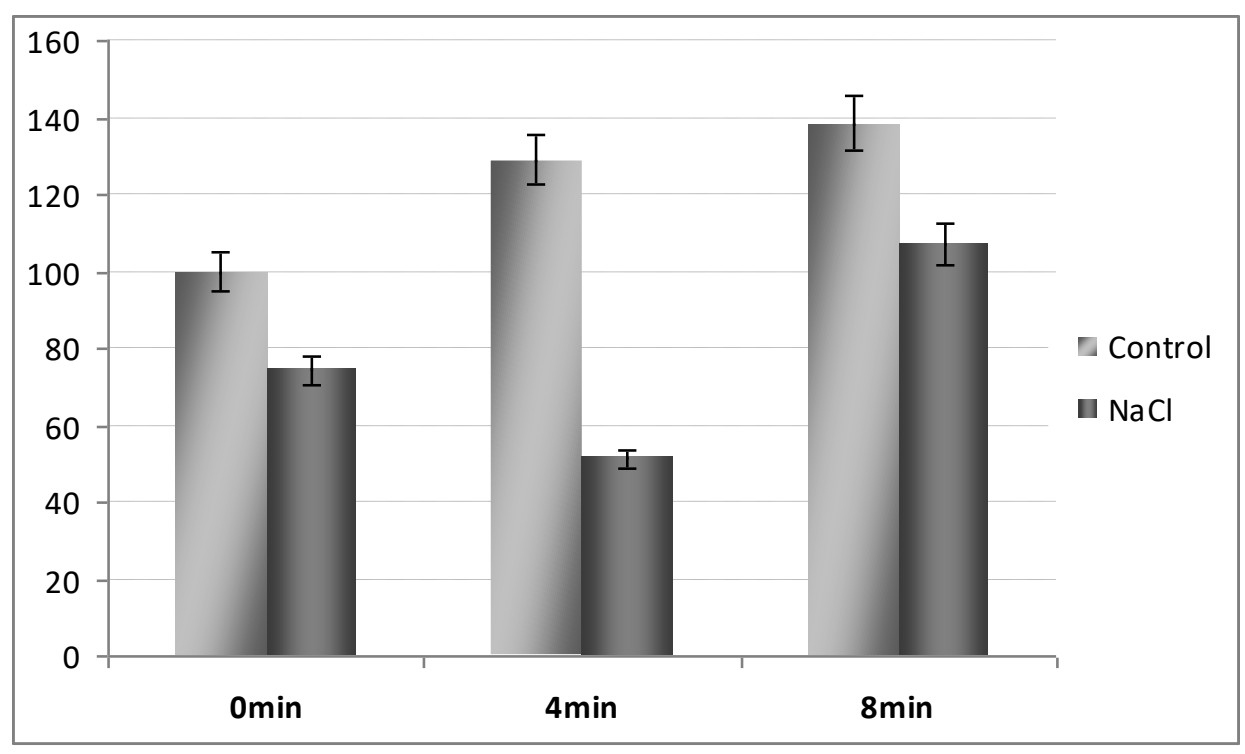

Figure 3. The proline content in pea seedlings roots in depend of salt or high temperature treatments. (On Y axis - \% in compare to control; On X axis - high temperature impact duration). 7 days after stressors impact.

For example, similar proline and spermine accumulation in Mesembryanthemum crystallinum leaves under the influence of salinity has been shown. At the same time, increased temperature combined with salinity does not lead to significant changes in proline concentration. It can indicate that proline biosynthesis is regulated by osmotic factors in the similar manner to biosynthesis of spermine [25]. Therefore, we can assume that salinization after hyperthermia, which affected only roots of seedlings triggered the signal transmission to other organs of plants and triggered the synthesis of protective compounds there.

The proline content in plants after the combination of salinity and high temperature impact (during 4 minutes) was below the control values. It can be explained by changes in proline-rich proteins metabolism, the synthesis of proline and the transport of proline to pea stem and leaves (for example as a signal molecule). Tere is opinion that heat shock by itself can not induce proline synthesis. It just makes the plant to be competent to response to following salinization and farther accumulation of this osmolite. The nature of the receptor by which the plant cell can perceive temperature signal is still not clear. There are presumptions that changes in cell membrane fluidity can case opening of calcium channels [26] and activation of calciumdependent pathways of signal transduction to the genome. Among other important intermediates may be active forms of oxygen or the products of lipids peroxidation [19] that can be formed by the influence of different stress factors on the living organisms.

\subsubsection{Heat shock in Combination with Preliminary Irradiation}

To study reaction of plant and accumulation of proline in response to radiation we suggest another set of experiments. It was also performed with heat shock in the form of 4 minutes heating to $44^{\circ} \mathrm{C}$, but in this case modification factor was acute X-ray in doses up to $25 \mathrm{~Gy}$.

Amino acids have different resistance to ionizing radiation. It depends on different factors, one of which is whether they are in a free state or included in the protein molecule. Thus, after irradiation the protein tyrosine breaks down faster than free tyrosine, but phenylalanine, arginine, proline and histidine in the proteins are more stable. Aromatic and heterocyclic amino acids can be put in the following order by sensitivity to ionizing radiation: histidine $>$ phenylalanine $>$ tyrosine $>$ tryptophan. It is known that the most stable to irradiation 
are proline and hydroxyproline. In two days after stress factors impact plant material was gathered and amino acid levels (Figure 4) were measured and analyzed.

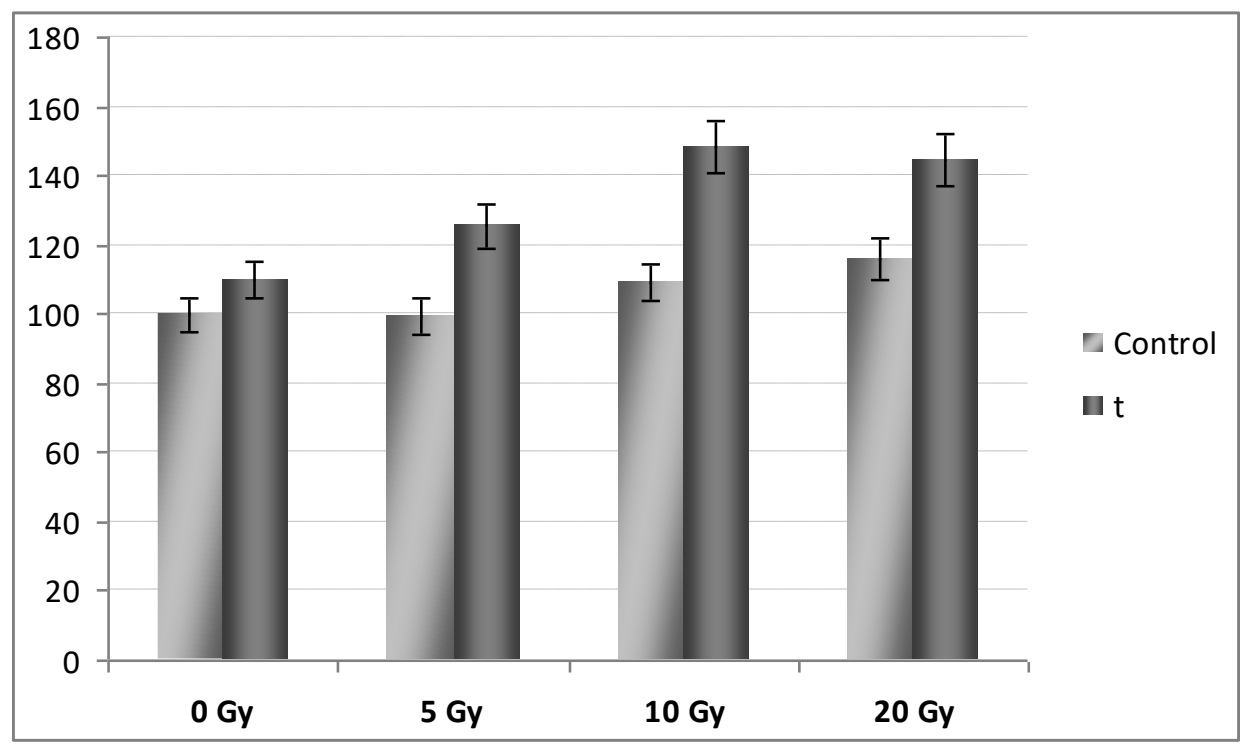

Figure 4. Proline accumulation in the pea seedlings in response to hyperthermia with and without preliminary irradiation (On Y axis - \% in compare to control; On X axis - dose of radiation impact). 2 days after stressors impact.

The amino acid level was not changed significantly in response to radiation as in response to other treatments. However, it is remarkable that the proline levels increased in the case of preliminary irradiation and undergo hyperthermia impact. This type of interaction of stressors can be classified as potentiation. It means that the radiation itself does not affect the proline concentration in the plant roots but it can modify responses to hyperthermia. The evidence of this is the increase of amino acid 1.5 times in group of both stress treatments in compare to either control group or the group of hyperthermia impact only.

\subsubsection{Free Proline Concentration in Pea Seedlings after Salinization with Preliminary Irradiation}

As it was mentioned previously in a lot of plants the concentration of free proline in stem and in roots or other organs differs insignificantly and mainly correlates. Although some studies indicate that this amino acid accumulation in different parts of seedling supposes to be the tissue-specific.

Concentration of proline in different parts of the plant is equalized in later term suffer the stressors impact. The authors [27] note that amount of proline in both roots and leaves of corn plants has no difference in control on the $14^{\text {th }}$ day. In our study we evaluated amino acid content only in roots of pea seedlings to increase the reliability of measurements (by excluding chlorophyll-contained tissues from colorimetric estimations). The growth of proline concentration can be used as a quantitative measurement of stress reaction.

Proline was suggested as phyto-indicator for chemical contamination identification, because this amino acid is able to be accumulated in plant's vegetative organs in abiotic stresses environment [28]. It is known that the stronger a plant is affected by unfavorable environmental conditions, the higher the level of proline in its tissues. It has been repeatedly shown that the level of this amino acid rises more in plants that are more sensitive to stress than in resistant species [29]. 
Pea is sufficiently radio- and salinity-sensitive plant species so it was expected to see a fairly strong response of the metabolic apparatus and variability of the proline concentration. number of authors suggest that in annual plants the increase in proline concentration can be barely traced in 30 minutes after salinity stress, e.g. in case of millet [30], 4 hours in case of arabidopsis [31] and up to 7-10 days in case of tobacco [32].

A distinguishing feature of $\mathrm{NaCl}$ impact is its dual nature in compare to other abiotic stress factors: both toxic affect on ionic overflow excess and osmotic stress [33-35]. Salinity stress cause over reduction of photosynthetic chain, production of active forms of ROS and consequently oxidative stress [36]. In case of salinization $\mathrm{Na}^{+}$and $\mathrm{Cl}^{-}$ions penetrate into the cells. These toxic ions lead to increase of proline accumulation, as expected, since the role of proline as a detoxicant is well known [12]. The same phenomenon was found in studies of another salts. It has been discovered that $\mathrm{Cd}^{2+}$ ion is one of the most severe ecotoxicants, which entails the activation of cellular mechanisms of plant stress tolerance that is caused by free proline accumulation [37].

In our studies on the $2^{\text {nd }}$ day after the stress impact the highest increase of proline level was detected in plants after high doses of ionizing radiation. At 15-25 Gy the content of proline rise up to about $140 \%$ in compare to control. At the same time we observed minor increase of proline content for plants after 5 Gy with or without salinity (Figure 5).

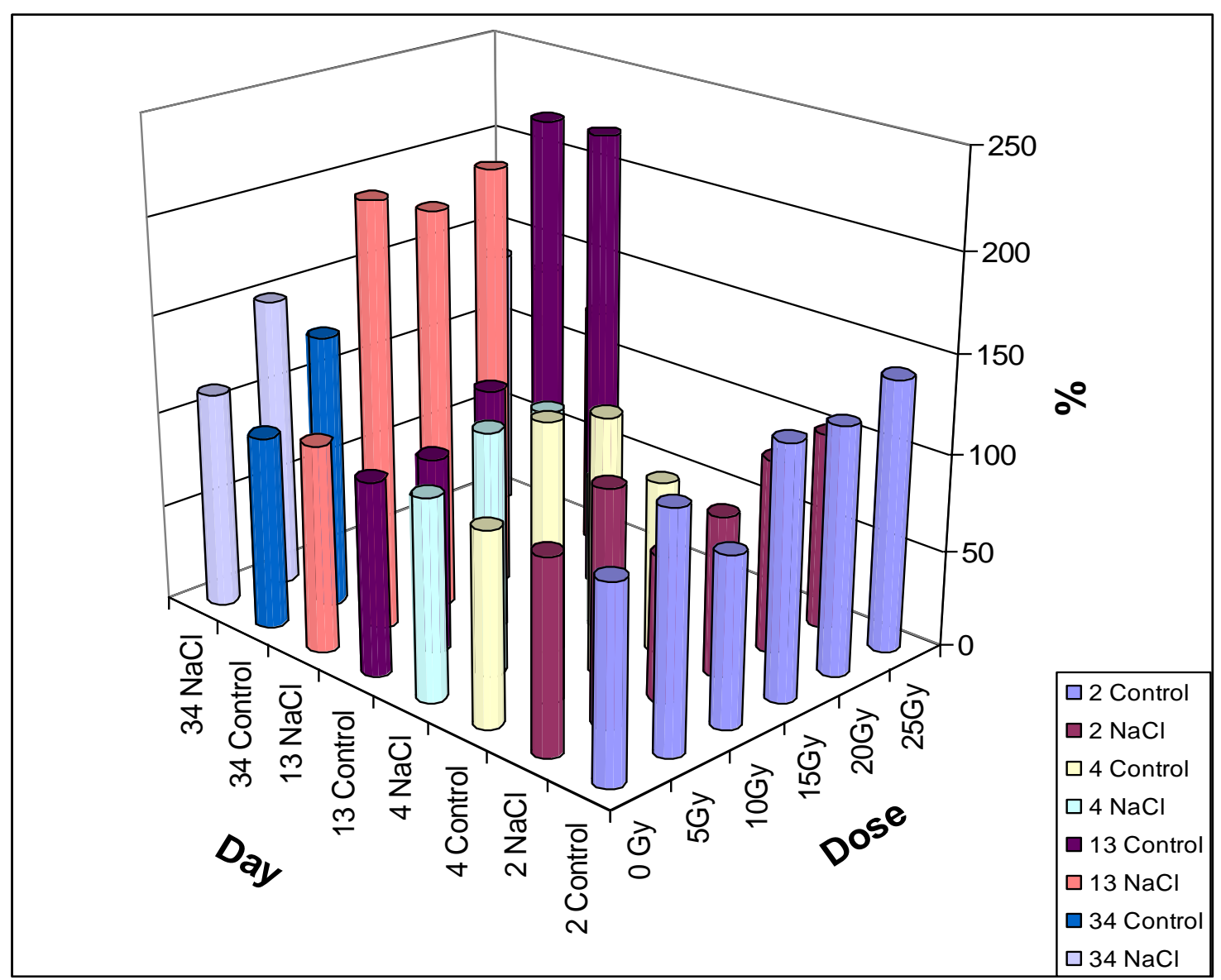

Figure 5. Free proline concentration in pea roots. 2-34 days after salinity, with or without irradiation. (\% in compare to control).

It may be caused by the activation of genes expression that is involved in proline synthesis and disintegration. For instance, for Arabidopsis leaves it was shown that in 12 hours after the stress treatment in 100 and $150 \mathrm{mM}$ sodium chloride, the mRNA level of the gene encoding the 
key enzyme in proline synthesis - P5CS (pyroline-5-carboxylate reductase) increases by 2.5 and 3.5 folds, respectively [38].

In higher plants more than 20 genes are involved in processes of proline synthesis and disintegration [39]. Among them, two genes are especially worth mentioning - AtP5CS2 and AtP5CS1. It is known that both genes are activated by low temperature, drought, high salt concentrations, and osmotic stress. They control the synthesis of P5CS (pyrroline-5-carboxylate synthetase) enzyme (key bi-functional enzyme of proline biosynthesis biochemical pathway). It is a "narrow bottle neck" in the biosynthesis of this amino acid and plays a major role in reactions to stress [40]. Another important enzyme of proline synthesis is ornithine aminotransferase (OAT). However, the role of this gene in controlling plant stress tolerance is still doubtful, since its type of expression differs from typical stress-specific variants [41].

The P5CS gene cloned from Vigna aconitifolia encodes a bifunctional enzyme with the catalytic activities of $\gamma$-glutamyl kinase and glutamyl- $\gamma$-dimial dehydrogenase. This enzyme catalyzes the conversion of glutamate to $\Delta^{\prime}$-pyrroline- $v 5$-carboxylate, which is then restored to proline. Transgenic tobacco plants (with P5CS gene) produced up to 10-18 times more proline and higher total biomass than control plants. Increasing the concentration of osmotic active compound forward to an increase in osmotic potential (reduction of water potential) and to facilitate survival under conditions of water deficiency.

For our experiments under radiation or salinity impact it would be informative to search for similar genes and intermediate compounds that affect the level of their expression and signal transduction to explain the role of proline in the cross-adaptation of plants.

It is well known that among a large group of plant proteins there are special proline rich proteins (PRPs). They are included in the cell walls [42]. PRPs molecules containing several repeats of a short proline-rich sequences to which hydroxyproline can be added. Intra- and intermolecular cross-links that creates the structure of the cell wall are formed.

On the $13^{\text {th }}$ day we noted significant growth of proline concentration. There are concerns to all groups where stress factors affect individually or in combinations. Exception was the group of 5Gy irradiated plants, in which the concentration of proline did not differ much from the control group. This may be due to the fact that previous studies of the seedlings growth reactions showed not suppression, but stimulation of root length growth for such a non-critical dose.

On the second day after stressors impact content of amino acid was $20 \%$ higher than in control group. Perhaps the proline that appeared on the first days of plant's response to minor damage was subsequently involved in the synthesis of other substances necessary for the cell in that moment. At the same time high doses of radiation still inhibited the synthesis of proline after salinization, in contrast to doses up to $10 \mathrm{~Gy}$. In this dose range, apparently, as in the experiment with tobacco, we can agree with the authors' statement. They believe that as the pathological effect of salt is associated with the penetration of toxic ions into the cell, on the $7^{\text {th }}-10^{\text {th }}$ day (in our case - on $13^{\text {th }}$ day) their negative impact on the internal structures of the cell may have began. This led to activation of plant protective reactions, both to the active response of cells and to the enhancement of its synthesis, and to the destruction of cell walls structures with the release of free proline [32].

On the $34^{\text {th }}$ day of experiment the amount of proline in plants after salinization with or without preliminary irradiation was slightly higher than the control values on about $20 \%$. Significant difference (up to 50\%) was observed only in case of salinization combined with high radiation dose of $25 \mathrm{~Gy}$. Apparently as time passes a process of restoration of plants and therefore alignment of amino acid concentrations takes place. 
Another interesting fact was that according to our data the accumulation of proline in all groups turned out to be lower than the in control ones on $90^{\text {th }}$ day after the stressors impact on pea seedlings. The authors [30] arrived at a conclusion that hydrogen peroxide produced by NADPH-oxidase plays role in activating the plant reactions that necessary to salinization adaptation, in particularly proline accumulation. Preliminary treating the seedlings with hydrogen peroxide or NADPH-oxidase inhibitor before the salinization reduced the usual response to salinity stress by decrease concentration as of hydrogen peroxide as proline.

It should be noted that under the impact of ionizing radiation in addition to direct energy transfer to molecules, various radiolysis products are formed in the presence of oxygen. These products have oxidative properties and include hydrogen peroxide $\mathrm{H}_{2} \mathrm{O}_{2}$. So $\mathrm{H}_{2} \mathrm{O}_{2}$ could be the reason for proline increase in irradiated seedlings (15-25 Gy). When radiation (10 and $15 \mathrm{~Gy}$ ) was combined with salinity stress, proline concentration was $20-30 \%$ below control level. It is true for early stages of organism's response to radiation impact. In this time changes in physical, chemical and biological features of molecules defines damages of cells and cells active response is formed. The duration of this phase can be prolonged for a long period up to the lifespan of the organism. Thus on the following steps the indirect impact of radicals and hydrogen peroxide on proline level is eliminated and its concentration begins to depend on other factors. For example, the accumulation of proline can be regulated by abscises acid (ABA) and $\mathrm{Ca}^{2+}$ ions [43-44]. ABA activates the synthesis of proline and whole arrays of stress proteins: aquaporins, dehydrins, osmotin, proline synthesis enzymes. It assists in the accumulation of hydrated water in osmotic stress, inhibits the synthesis of RNA and normal proteins. It is shown that $\mathrm{Ca}^{2+}$ and a number of other inorganic ions change the activity of proline dehydrogenase, an enzyme that controls the catabolism of this amino acid [44-45].

On $13-34^{\text {th }}$ day after irradiation and salinization seedlings accumulated more proline than after salinization only that indicates the loss of radiation's protection effect on late phases of pea development. At the same time the growth of the main root passes into the deceleration phase while growth of lateral roots increases. It is associated with destruction of the cell walls and activation of the intercalary meristem of the main root, which leads to the increase in proline quantity especially on $13-34^{\text {th }}$ days after stress factors impact [46].

Proline is more characterized by not osmoregulatory but protective function. It affects the intracellular regulation between the cytoplasm and vacuoles, regulates the $\mathrm{pH}$ of cytosol, protects enzymes and intracellular structures and inactivates free radicals. It is the source of carbon and nitrogen for recovery after stress [47] takes part in signal transduction under the stress in plant. Ambiguity of proline accumulation under the impact of various stressors and their combinations may indicate the appearance of other compounds that affect the amino acid synthesis system and its degradation, signal transmission during certain stages of plant's response [48]. The experiments show that the level of proline raises first and later polyphenolic compounds are added to it [31].

A high level of free proline in both salt-tolerant and salt-sensitive plant genotypes is a display of differently directed reactions in tobacco plants. Therefore its absolute values can not be an unambiguous indicator of tolerance to salinity [32]. In addition, it is also necessary to consider the probability of other protective osmotically active substances appearance.

Further experiments on the adaptation of pea with different stress factors or their combinations, similar to experiments on pea with cross-cultivation in polyethylene glycol (PEG) and $\mathrm{NaCl}$ solutions [49] or our experiments, can be useful not only to achieve a certain level of proline in the tissue of seedlings to increase their integrated resistance to stress. But they also are promising for understanding the general mechanisms of crosstalk signal transduction response of the plants to stress. 


\section{CONCLUSION}

Plants are supposed to undergo two different strategy stages to survive in harmful environment non-specific stress reaction and specialized adaptation that differs in their biological functions and duration. We observed deviation of plants reactions under combination of stress factors from additive perceive effects to synergism or antagonism that can represent crosstalk of signal system.

Radiation can modify salinity and heat stress tolerance of seedlings. Irradiation of seedlings over $10 \mathrm{~Gy}$ stimulated accumulation of proline on the first stages of plant's response. Following after irradiation high temperature stress increased proline level in roots in all range of radiation. On the contrary, following after irradiation salinity stress decreased proline concentration for high doses (15-25 Gy). High temperature has more strong effect on the seedlings than salinity stress ones. Heating causes modulating effect on the process of proline accumulation after salt treatment in depend of the duration of the stress influence on the plants. Unlike the growth parameters of the seedlings proline accumulation was not changed as significantly in response to ionizing radiation.

The highest level of proline was observed at 2-3 ${ }^{\text {rd }}$ week after stressors impact (up to three fold higher than control value) for plants irradiated 5-25 Gy coupled with salinity and after 1520 Gy irradiated only. It may be consequence of proline synthesis enhancement and the destruction of cell walls PRPs. The non-linear relationship between growth reactions and proline concentration may indicate the presence of other (specific) adaptive plant responses to stress. It is possible that cross talk between signal systems takes place. This may lead to synthesis interact other substances that influence on proline synthesis and its degradation, signal transduction and plant's adaptive potential in general.

\section{Acknowledgements}

This work was supported by grants IRSES GA-2013-612587 «Plant DNA tolerance». We thank our colleagues from Plant Science and Biodiversity Centre of Institute of Plant Genetics and Biotechnology (Slovak Academy of Sciences), especially to Katarina Klubicova and Viera Majercikova for advice and support. We would also like to acknowledge the support from Gennadiy and Dmytro Nesterenko, Sergey Litvinov, Andrii Potrokhov.

\section{Conflict of Interests}

Authors declare that there is no conflict of interests.

\section{Orcid}

Olena Nesterenko (iD) https://orcid.org/0000-0002-7764-4635

Namik Rashydov (iD) https://orcid.org/0000-0001-5387-4877

\section{ResearchGate}

Olena Nesterenko https://www.researchgate.net/profile/Olena_Nesterenko2

Namik Rashydov https://www.researchgate.net/profile/Namik_Rashydov

\section{REFERENCES}

[1] Vahdati, K., \& Lotfi, N. (2013). Abiotic Stress Tolerance in Plants with Emphasizing on Drought and Salinity Stresses in Walnut, Abiotic Stress - Plant Responses and Applications in Agriculture, (Eds.): Kourosh Vahdati, InTech, https://www.intechopen.com/books/abiotic-stress-plant-responses-and-applications-inagriculture/abiotic-stress-tolerance-in-plants-with-emphasizing-on-drought-and-salinitystresses-in-walnut. 
[2] Rashydov, N., Kliuchnikov, O., Seniuk, O., et al. (2012). Radiobiological Characterization Environment Around Object "Shelter" In book: Nuclear Power Plant, (Eds.): Soon Heung Chang. Chapter 7, 231- 279. http://www.intechopen.com/profiles/25919/namik-rashydov

[3] Athar, H.R., \& Ashraf, M. (2009). Strategies for crop improvement against salt and water stress: An overview. In: Salinity and water stress: Improving crop efficiency. Tasks for Vegetation Sciences (Eds.): M. Ashraf, M. Ozturk and H.R. Athar. Springer-Verlag, The Netherlands, 44, 1-16.

[4] FAOSTAT (2011) (faostat.fao.org).

[5] Martins, A.C. (2011). Change and Aging Senescence as an Adaptation. Plos One, 6(9), 112.

[6] Trindade, L.S., Aigaki, T., Peixoto, A. (2013). A novel classification system for evolutionary aging theories. Front Genet, 4(25), 1-8.

[7] Mundy, J., H., Nielsen, B., \& Brodersen P. (2006). Crosstalk. Trends in Plant Science, 11(2), 63-64.

[8] Wei, J., van Loon, J.J., Gols. R. (2014). Reciprocal crosstalk between jasmonate and salicylate defence-signalling pathways modulates plant volatile emission and herbivore host-selection behavior. Exp Bot., 65(12), 3289-3298.

[9] Fujita, M, Fujita Y, Noutoshi, Y. (2006). Crosstalk between abiotic and biotic stress responses: a current view from the points of convergence in the stress signaling networks. Curr Opin Plant Biol., 9(4), 436-442.

[10] Hurst, A., Grams, T., Ratajczak, R. (2002) Effects of Salinity, High Irradiance, Ozone, and Ethylene on Mode of Photosynthesis, Oxidative Stress and Oxidative Damage in the C3/CAM Intermediate Plant Mesembryanthemum Crystallinum L. Plant Cell, 27, 187-197.

[11] Morgan, M.J., Lehmann, M., Schwarzlander, M., Baxter, Ch. J. Sienkiewicz-Porzucek, A., Williams, T.C.R., Schauer, N., Fernie, A.R., Fricker, M.D. (2008). Decrease in manganese superoxide dismutase leads toreduced root growth and affects tricarboxylic acid cycle flux and mitochondrial redox homeostasis. Plant Physiology, 147, 101-114.

[12] Szabados, L., Savoure, A. (2009). Proline: a multifunctional amino acid. Trends Plant Sci., 15(2), 89-97.

[13] Carvalho, K., Campos, M.K., Domingues, D.S., Pereira, L.F., Vieira, L.G. (2013). The accumulation of endogenous proline induces changes in gene expression of several antioxidant enzymes in leaves of transgenic. Swingle citrumelo // Mol. Biol. Rep., 40, 32693279.

[14] Mattioli, R., Costantino, P., \& Trovato, M. (2009). Proline accumulation in plants: Not only stress. Plant Signaling and Behavior, 4(11), 1016-1018.

[15] Funck, D., Winter, G., Baumgarten, L., Forlani, G. (2012). Re-quirement of proline synthesis during Arabidopsis reproductive development. BMC Plant Biology, 12,1-12

[16] Nesterenko, O. G., Rashydov, N.M. (2017). Evaluation of the correlation between proline and water content of the Pisum sativum $L$. roots under abiotic stress factors influence. Biological systems, 9(2), 192-196.

[17] Hossain, Z, Nouri, M.Z, Komatsu, S. (2012). Plant cell organelle proteomics in response to abiotic stress. Proteome Res., 11(1), 37-48.

[18] Carillo, P., Gibon, Y. (2016). Extraction and determination of proline. ResearchGate. https://www.researchgate.net/publication/211353600.

[19] Чудинова, Л. А., Суворов, В. И. (2011). Роль некоторых низкомолекулярных соединений в механизме перекрестной адаптации растений. Вестник пермского университета (Биология), 1, 17-20. 
[20] Stein, H., Honig, A., Miller, G., Erster, O., Eilenberg, H., Csonka, L.N. (2011). Elevation of free proline and proline-rich protein levels by simultaneous manipulations of proline biosynthesis and degradation in plants. Plant Sci.,181, 140-150.

[21] Battaglia, M., Solorzano, R.M., Hernandez, M., Cuellar-Ortiz, S., Garcia-Gomez, B., Marquez, J., Covarrubias, A.A. (2007). Proline-rich cell wall proteins accumulate in growing regions and phloem tissue in response to water deficit in common bean seedlings. Planta, 225,1121-1133.

[22] Карташов, А.В., Иванов, Ю.В., Радюкина, Н.Л., Шевякова, Н.И., Кузнецов, В.В. (2006). Активация некоторых защитных систем в растениях Thellungiella halophila при действии $\mathrm{NaCl}$, Известия ПГПУ. Естественные науки, 1 (5), 57-61.

[23]. Hayat, S, Hayat, Q, Alyemeni, MN, Wani, AS, Pichtel, J, Ahmad, A. (2012). Role of proline under changing environments: a review. Plant Signal Behav., 7(11), 1456-1466.

[24] Mattioli, R., Costantino, P., Trovato, M. (2009). Proline accumulation in plants: not only stress. Plant Signal. Behav., 4, 1016-1018.

[25] Shevyakova, N. I., Shorina, M. V. Rakitin, V. Yu., \& Kuznetsov, Vl. V. (2006). StressDependent Accumulation of Spermidine and Spermine in the Halophyte Mesembryanthemum crystallinum under Salinity Conditions. Russian Journal of Plant Physiology, 53(6), 739-745.

[26] Карпец, Ю.В., Колупаев, Ю.Е. (2009). Ответ растений на гипертермию: молекулярно-клеточные аспекты, Вісник Харківського національного аграрного університету. Серія Біологія, 1(16), 19-38.

[27] Михальская, С.И., Матвеева, А.Ю., Сергеева, Л.Е., Кочетов, А.В., Тищенко, Е.Н. (2013). Исследование содержания свободного пролина в растениях кукурузы, трансформированных in-planta с использованием LBA4404, несущего pBi2E c двухцепочечным РНК-супрессором гена пролиндегидрогеназы. Известия Самарского научного иентра Российской академии наук, 13(3), 1662-1665

[28] Данилина, Л.И., Фролов, Д.И. (2015). Оценка уровня загрязненности земель сельскохозяйственного назначения. Инновационная техника и технология, 3(4), 5865.

[29] Кириллов, А.Ф., Козьмик, Р.А., Даскалюк, А.П., Кузнецова, Н.А., Харчук, О.А. (2013). Оценка содержания пролина в растениях сои при воздействии засухи и засоления. Доклады по экологическому почвоведению, 1(18), 194-201.

[30] Вайнер, А. А., Колупаев, Ю. Е., Ястреб, Т. О. (2013). Участие пероксида водорода в индуцировании накопления пролина в растениях проса при действии $\mathrm{NaCl}$. Biсник Харківського національного аграрного університету (біологія), 2 (29), 32-38.

[31] Діденко, Н. О., Волков, Р. А., Панчук, І. І. (2016). Вплив сольового сресу на вміст проліну та поліфенольних сполук у Arabidopsis thaliana. Біологічні системи, 8(1), 3539.

[32] Сергєєва, Л., Броннікова, Л. (2016). Пролін-опосередковані реакції тютюну на дію засолення, Науковий вісник Східноєвропейського начіонального університету імені Лесі Украӥнки (Ботаніка), 12, 15-19.

[33] Hasegawa, P.M., Bressan, R.A., Zhu, J.-K., Bohnert, H.J. (2000). Plant cellular and molecular responses to high salinity. Plant Physiol. Plant Mol. Biol., 51, 463-499.

[34] Sneha, S., Rishi, A. Chandra, S. (2013). Effect of short term salt stress on chlorophyll content, protein and activities of catalase and ascorbate peroxidase enzymes in Pearl Millet. Am. J. Plant Physiol., 9(1), 32-37. 
[35] Deinlein, U., Stephan, A.B., Horie, T., Luo, W., Xu, G., Schroeder, J.I. (2014). Plant salttolerance mechanisms. Trends Plant Sci., 19(6), 371-379.

[36] Falleh, H., Jalleli, I., Ksouri, R., Boulaaba, M., Guyot, S., Magné, C., Abdelly, C. (2012). Effect of salt treatment on phenolic compounds and antioxidant activity of two Mesembryanthemum edule provenances. Plant Physiol. Biochem, 52, 1-8.

[37] Тажибаева, Т.Л., Масимгазиева, А.С. (2013). Свободный пролин как индикатор металлоустойчивости пшеницы. KazNu Bulletin. Ecology series, 2/2(38), 351-355.

[38] Liu, J., Zhu, J. K. (1997). Proline accumulation and salt-stress-induced gene expression in a salt-hypersensitive mutant of Arabidopsis. Plant Physiol., 114(2), 591-596.

[39] Kavi Kishor, P.B., Sangam, S., Amruhta, R.N., Sri Laxmi, P., Naidu, K.R., Rao, K.R.S.S. Rao Sreenath, Reddy, K.J., Theriappan, P., Sreenivasulu, N. (2005). Regulation of proline biosynthesis, degradation, uptake and transport in higher plants: Its implications in plant growth and abiotic stress tolerance. Current Science, 88 (3), 424-436.

[40] Kiyosue, T., Yoshiba, Y., Yamaguchi-Shinozaki, K., Shinozaki, K. (1996). A nuclear gene encoding mitochondrial proline dehydrogenase, an enzyme involved in proline metabolism, is upregulated by proline but downregulated by dehydration in Arabidopsis. Plant Cell., 8, 1323-1335.

[41] Колодяжная, Я.С., Куцоконь, Н.К., Левенко, Б.А., Сютикова, О.С., Рахметов, Д.Б., Кочетов, А.В. (2009). Трансгенные растения, толерантные к абиотическим стрессам. Цитология и генетика, 2, 72-93.

[42] Dvořáková, L., Cvrčková, F., Fischer, L. (2007). Analysis of the hybrid proline-rich protein families from seven plant species suggests rapid diversification of their sequences and expression patterns. BMC Genomics, 412, 1-16.

[43] Карпец, Ю.В., Колупаев, Ю.Е. (2009). Ответ растений на гипертермию: молекулярно-клеточные аспекты, Вісник Харківського національного аграрного університету. Серія Біологія, 1(16), 19-38.

[44] Садыгов, С.Т., Акбулат, М., Ахмедов, В. (2002). Роль Са2+ в передаче стрессовых сигналов у проростков пше ницы. Биохимия, 67(4), 587-594.

[45] Hare, P.D., Cress, W.A. (2003) Metabolic implications of stress-induced proline accumulation in plants. Plant growth regulation, 21(2), 79-102.

[46] Кравец, Е.А., Бережная, В.В., Сакада, В.И., Рашидов, Н.М., Гродзинский, Д.М. (2012). Структурная архитектоника апикальной меристемы корня в связи с количественной оценкой степени ее радиационного поражения. Цитология $u$ генетика, 2, 12-23.

[47] Франко, О.Л., Мело, Ф.Р. (2000). Осмопротекторы: ответ растений на осмотический стресс.Физиология растений, 47(1), 152-159.

[48] Нестеренко, О., Гродзинский, Д., Рашидов, Н., Ланчикова, В. (2015). Взаимодействие солевого и гипертермического стрессовых факторов с ионизирующим излучением у проростков гороха. Agrobiodiversity for improving nutrition, health and life quality. Nitra: Slovak University of Agriculture, 511-514.

[49] Гаджиева, И.Х., Алиева, 3.М., Рамазанова, П.Б. (2010). Кросс-адаптация растений к почвенному засолению и тяжелым металлам, Экология растений. Юг России: экология, развитие, 1, 26-32. 